\title{
Is the breeding success of the White-throated Dipper Cinclus cinclus in Hedmark, Norway influenced by acid rain?
}

\author{
Trond Øigarden ${ }^{1} \&$ Arne Linløkken²
}

Øigarden, T. \& Linløkken, A. 2010. Is the breeding success of the White-throated Dipper Cinclus cinclus in Hedmark, Norway influenced by acid rain? - Ornis Norvegica 33: 118-129.

The aim of this study was to investigate if the White-throated Dipper Cinclus cinclus in Hedmark has problems related to acidification of its habitat. Thirty-three breeding attempts were found in the study area in 1998 and water samples were taken at 29 localities and bottom samples at 20. The number of young in the nest at day 8-10 after hatching was used as a proxy of breeding success and 26 breeding attempts were successful. There was found a significant positive correlation between number of young in the nest and the parameters $\mathrm{pH}$, alkalinity and calcium concentration at the locality. At least one unsuccessful breeding was probably related to low calcium.

${ }^{1}=$ Natural History Museum, University of Oslo, P.O. Box 1172 Blindern, NO-0318 Oslo, Norway

${ }^{2}=$ Hedmark College, Faculty of education and natural science. Box 4010 Bedriftssenteret, N-2306 Hamar, Norway

Key words: White-throated Dipper, Cinclus cinclus, acidification, $\mathrm{pH}$

Corresponding author: Trond Øigarden, Natural History Museum, University of Oslo, P.O. Box 1172 Blindern, NO-0318 Oslo, Norway.E-mail: trond.oigarden@nhm.uio.no.

\section{INTRODUCTION}

Acidified rain has probably affected water systems in Norway since early in the $20^{\text {th }}$ century. In southern Norway, at least $55000 \mathrm{~km}^{2}$ have been seriously affected by acidification (Kroglund $e t$ al. 1994, Overrein et al. 1980) causing the extermination and reduction of numerous fish populations. Negative effects of acidification have been shown for many aquatic species (Brewin et al. 1998, Muniz 1990), but little is known about the effect of acid rain on birds and mammals.

Two studies of the Pied Flycatcher Ficedula hypoleuca nesting near the shore of an acid lake in North Sweden were conducted in the 1970s, and showed that $30-40 \%$ of the nests contained eggs with defect eggshells, and several cases of nest desertion during egglaying or incubation were observed (Nyholm 1981, Nyholm \& Myhrberg 1977). A theory that aluminium poisons birds as well as fish (Rosseland et al. 2001) in acid lakes was proposed. Birds get aluminium through eating fresh water insects. This hypothesis was, however, weakened after findings of high aluminium values in insects from both acidified and non-acidified lakes (Nybø \& Jerstad 1997).

Drent \& Woldendorp (1989) showed that Great Tits Parus major living in an acidified forest area had similar problems; building nests without laying eggs, desertion of the nests before the start of incubation or production of eggs with poor eggshells. Other stationary birds like Blue Tit Cyanistes caeruleus, Coal Tit Periparus ater, Nuthatch Sitta europaea and Great Spotted Woodpecker Dendrocopos major showed similar 
patterns, whereas the migrating Pied Flycatcher did not. This difference was explained by lower calcium intake by stationary compared to migrating birds, due to the migrating bird's opportunity to fill their calcium store before arrival at the nesting area. It was later found that the Pied Flycatchers eat more calcium-rich prey than the Great Tit (Graveland \& van Gijzen 1994). The hypothesis about calcium deficit was strengthened through experiments placing small feeders with snail shells outside some of the Great Tit nest-boxes in Holland (Graveland et al. 1994). The Great Tit females fed on the snail shells and no more desertion behaviour was observed. Furthermore, the number of finished nests without eggs was reduced to near zero and the number of nests with one or more defect eggshell decreased.

In Norway, some studies on the White-throated Dipper Cinclus cinclus (hereafter called the Dipper) (Efteland 2006, Jerstad 1991, Nybø \& Jerstad 1997, Østnes et al. 1999) and on the breeding success of Pied Flycatchers and Great Tits nesting near acidified water (Jåbekk 1985) have been conducted. Jåbekk (1985) showed that nest desertion and nestling mortality were negatively related to the distance from the water, and Efteland (2006) found smaller broods in the most acidic parts of his study area in SW Norway. In the Dipper population in the watercourse of Lyngdal in Vest-Agder, behaviour similar, to that described for the Great Tits in Holland (Graveland et al. 1994) has been observed since the 1970s. The Dippers deserted newly-built nests without eggs or nests with 1-3 eggs, and the proportion of deserted nests increased from $12 \%$ in 1976 into $40 \%$ in 1996 (Nybø \& Jerstad 1997). Thinner eggshells and lower bone strength in Dippers from Vest-Agder than in Dippers from Nord-Trøndelag, an area with practically no acidification problem (SFT 2007), have also been documented (Nybø et al . 1997). Østnes et al . (1999) found a positive effect of placing crushed shells in the vicinity of nest sites on breeding success of Dippers suggesting that the Dippers in Vest-Agder may suffer from a lack of calcium. Tyler \& Ormerod (1994) have shown that may- flies (Ephemeroptera) are important food items early in the nestling period, whereas caddis flies (Trichoptera) are more important later. Several species of mayfly are vulnerable to acidification, and are absent at $\mathrm{pH}<5.5$ (Fjellheim \& Raddum 1990). This may potentially affect the nesting success of the Dipper.

The county Vest-Agder, where Dippers have been studied, is on the coast of southern Norway and is more affected by acid rain than any other part of the country due to high precipitation with low pH (SFT 2007). In our study area, in Hedmark in the SE Norway, precipitation is lower, and $\mathrm{pH}$ is 0.2 units higher than in Vest-Agder (SFT 2007). In general effects from acidification are therefore less pronounced, though fish populations have been affected (Hesthagen et al. 1999), and water analyses have indicated that some river systems are seriously affected by acidification (Rognerud 1992). We therefore hypothesized that acidification may affect the hatching success of Dippers in the most acidified and calcium-poor rivers of this area.

\section{MATERIAL AND METHODS}

\section{Study area}

The study was carried out in Elverum, Åmot, Løten, Våler and Åsnes councils in Hedmark (Fig. 1), in 1998. Geologically the study area can be divided into two, the southern part belonging to the bedrock area, consisting mainly of granite and gneiss, and the northern part belonging to the Sparagmite Region (Sigmond et al. 1984). The rocks in both areas weather slowly, but in the northern part, local occurrence of more easily weathering gabbros, slate and Cambric Silurian rocks cause higher $\mathrm{pH}$, alkalinity and calcium in the runoff. In addition there are heavy depositions from glacier rivers or glacier lakes along the rivers Julussa and Søre Osa (Jørgensen et al. 1997, Thoresen 1990). Søre Osa is regulated for hydro electrical power production. The study area is part of the taiga and the vegetation is dominated by pine Pinus silvestris and spruce 


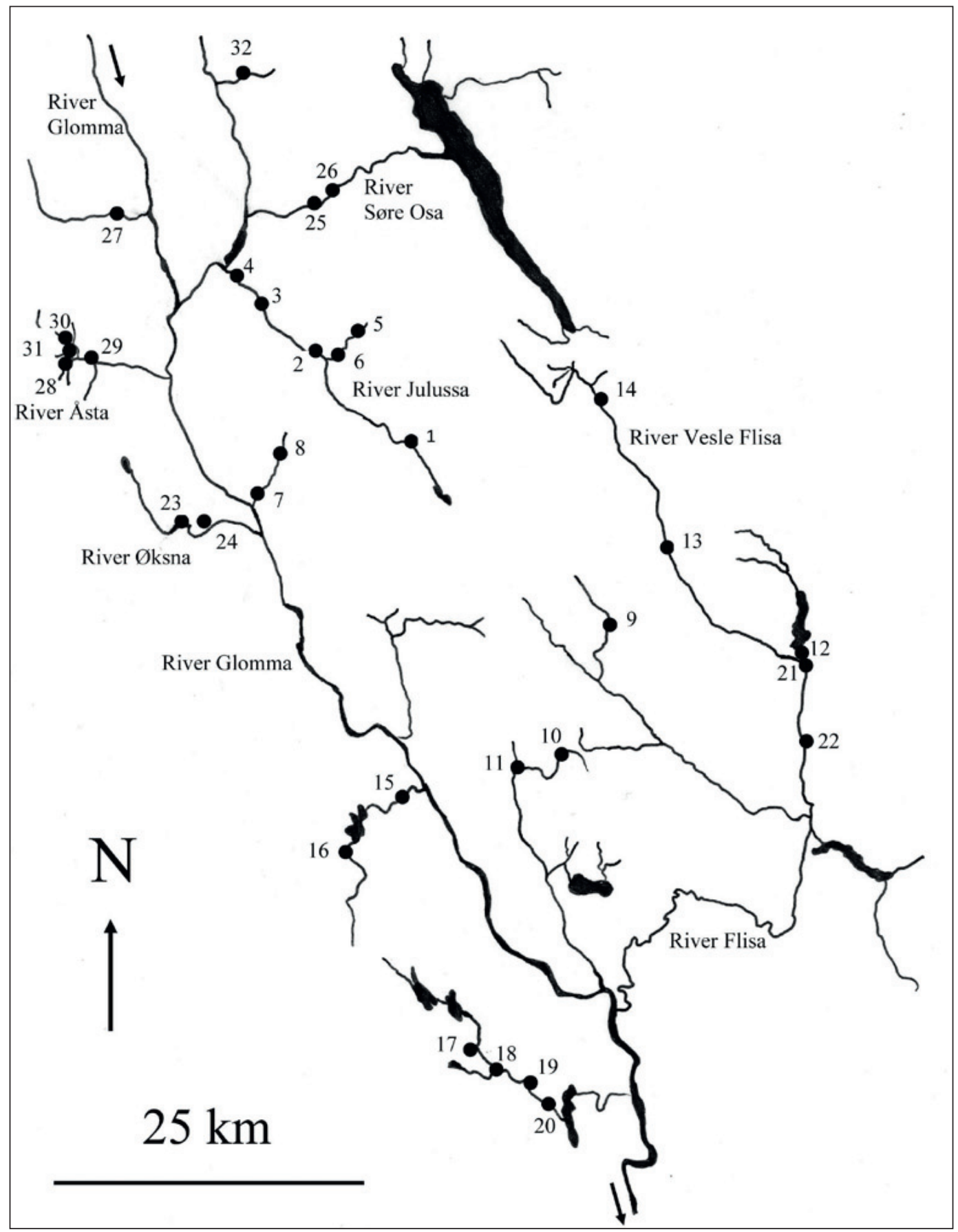

Figure 1. Map of study area, locations indicated with numbers referring to table 1. 
Picea abies, with some birch Betula pubescens and alder Alnus incana. The catchment area of river Vesleflisa has poorly developed quaternary deposits, and bogland is also abundant. Agricultural activity is negligible, except in some of the catchment area of the Julussa.

\section{Study Species}

The Dipper is a passerine bird in the family Cinclidae. It breeds throughout Norway, from the seashore to the willow belt (Gjershaug et al. 1994, Haftorn 1971). The Dipper catches almost all its food in the water. The nest is placed close to the water, on ledges, in cavities, below an overhang, behind waterfall, on stones in the river, under bridges, in old dams or in nest-boxes. The same nest can be used for several years. The clutch consists of 5 (4-8) eggs and is laid in May-June. The incubation period is $16(12-18)$ days, and the fledging period 20-24 days (Snow \& Perrins 1998).

\section{Sampling}

Field work lasted from April to June 1998. We visited all known nest sites in the study area and looked for new nest sites partly by visiting potential good nest sites and partly by walking along parts of rivers and streams. One river with high $\mathrm{pH}$ (Julussa) and one river with low pH (Vesleflisa) were chosen as objects for more thorough investigations to find every nest. Potential nest sites were visited early in the morning, because the Dipper is most active at that time of the day. The male patrols his territory actively and nests are built in the morning. The start of egg-laying was recorded in as many nests as possible during the afternoon, thus ensuring that the observer did not cause any desertions as the Dippers normally lay their eggs in the morning (Tyler \& Ormerod 1994). The nests were controlled again when the nestlings were 8-10 days old.

Three series of samples for water analysis were taken from 29 breeding localities; in the spring, in the summer and in the autumn, and later statistical analyses were based on mean values from each sampling station, and on the values from the October samples, assuming that these represent the real values. Samples were taken with $500 \mathrm{ml}$ plastic bottles and the salinity, $\mathrm{pH}$ and alkalinity were measured within 1-3 days. The other analyses of the water samples were done in the autumn. The analyses were done by Norwegian Standards (NS), and the analysis of aluminium was modified according to Dougan \& Wilson (1974).

The bottom fauna in each river was sampled to obtain a qualitative measure of the abundance of potential food items for the Dipper. We sampled aquatic insects from 20 localities, some of them covering more than one nest location. Two series of samples were taken, one in summer and one in autumn. Sampling was done by the kick method (Britain \& Saltveit 1984). Larvae of mayflies, stoneflies (Plecoptera) and caddis flies were identified to species level using the keys of Arnekleiv (1994), Lillehammer (1988), Edington \& Hildrew (1981) and Wallace et al. (1990).

\section{Statistical analyses}

Principal components analysis (PCA, varimax rotation, on SPSS program pack) was used to investigate the best association among biotic (number of nestlings per nest, relative abundance of mayfly, stonefly, caddis fly larvae) and abiotic factors $(\mathrm{pH}$, alkalinity, conductivity, calcium concentration, water colour). The data were not normally distributed (Shapiro-Wilk: $\mathrm{W}=0.86, \mathrm{p}$ $=0.0013$ ), therefore non parametric tests (Spearman) were used to test correlations between number of nestlings and environmental factors.

\section{RESULTS}

\section{Water quality}

Water $\mathrm{pH}$ ranged from 4.58 to 6.11 in May and from 5.31 to 6.76 in October (Table 1). The alkalinity ranged from 29.7 to $213.3 \mu \mathrm{ekv} / 1$, calcium content ranged from 1.1 to $3.1 \mathrm{mg} / \mathrm{l}$ in autumn, and total monomeric aluminium ranged from 67 to $219 \mu \mathrm{g} / \mathrm{l}$. Two water courses, river Julussa (location 1 -6) and river Vesleflisa (location 13 
Table 1. Number per nest of nestlings at the age of 8-10 days, some water quality parameters and main groups absent, $\mathrm{pH}$ Mean = mean of spring, summer and autumn sample, Tot. $N=$ number of specimens in the sample)

\section{Location Nestlings}

pH Mean
pH May
pH October
Alk. $\mu \mathrm{ekv} . / \mathrm{l}$
Cond. $\mathrm{mS} / \mathbf{m}$
Colour mg Pt/l

\begin{tabular}{|c|c|c|c|c|c|c|c|c|}
\hline 1 Storbekken & 5 & & 6.29 & 5.75 & 6.39 & 168.4 & 3.7 & 77.8 \\
\hline 2 Linderudbrua & 6 & & 5.97 & 5.15 & 6.44 & 178.4 & 3.3 & 66.3 \\
\hline 3 Mørstaddammen & 0 & Pred. & 6.04 & 5.14 & 6.49 & - & 3.4 & 61.5 \\
\hline 4 Fallet & 6 & & 6.11 & 5.17 & 6.60 & 213.3 & 3.6 & 56.7 \\
\hline 5 Ringsåsbekken 1 & 3 & & 5.67 & 4.85 & 6.09 & 93.8 & 2.1 & 105.0 \\
\hline 6 Ringsåsbekken 2 & 5 & & 5.66 & 4.87 & 6.11 & 88.8 & 2.1 & 102.4 \\
\hline 7 Letjerna & 3 & & 6.18 & 5.63 & 6.76 & 198.2 & 3.2 & 54.4 \\
\hline 8 Vesle-Letjerna & 4 & & 6.39 & 6.11 & 6.44 & 133.4 & 3.2 & 86.9 \\
\hline 9 Silkåa & 4 & & 5.02 & 4.58 & 5.33 & 46.7 & 1.9 & 119.1 \\
\hline 10 Holtsjøen ut & 2 & & 5.50 & 4.84 & 5.74 & 59.8 & 2.6 & 118.6 \\
\hline 11 Dipåa & 5 & & 5.71 & 5.18 & 6.01 & 89.0 & 3.0 & 122.1 \\
\hline 12 Haldammen & 0 & Dest. & 5.14 & 4.84 & 5.38 & 30.2 & 1.6 & 109.3 \\
\hline 13 Kjerka & & Abs. & 5.17 & 4.72 & 5.44 & 30.6 & 1.7 & 121.5 \\
\hline 14 Hådammen & & Abs. & 5.39 & 5.05 & 5.34 & 45.6 & 1.8 & 152.2 \\
\hline 15 Bronkåa & 5 & & 5.78 & 5.34 & 6.36 & 53.4 & 2.2 & 65.6 \\
\hline 16 Sortåa & 3 & & 5.12 & - & 5.33 & 29.7 & 1.8 & 153.0 \\
\hline 17 Veståa 1 & 0 & Dest. & 5.74 & - & 5.98 & 49.0 & 2.1 & 108.9 \\
\hline 18 Veståa 2 & 4 & & 5.53 & 5.35 & 5.97 & 49.1 & 2.0 & 130.9 \\
\hline 19 Veståa 3 & 4 & & 5.52 & 5.3 & 5.92 & 59.2 & 2.0 & 111.1 \\
\hline 20 Veståa 4 & 5 & & 5.52 & 5.3 & 5.92 & 59.2 & 2.0 & 111.1 \\
\hline 21 Ulvåa & 6 & & 5.64 & 5.27 & 5.98 & 94.1 & 1.9 & 98.7 \\
\hline 22 Nedre Flisfallet & 3 & & 5.52 & 5.20 & 5.87 & 41.3 & 1.8 & 91.2 \\
\hline $23 \varnothing \mathrm{ksna} 1$ & 3 & & 4.99 & 4.87 & 5.31 & 31.9 & 1.8 & 128.8 \\
\hline $24 \varnothing \mathrm{ksna} 2$ & 0 & Dest. & 4.99 & 4.87 & 5.31 & 31.9 & 1.8 & 128.8 \\
\hline $25 \mathrm{~S}$ Osa 1 & 5 & & 6.05 & - & 6.03 & 78.9 & 2.1 & 109.9 \\
\hline $26 \mathrm{~S}$ Osa 2 & 6 & & 6.05 & - & 6.03 & 78.9 & 2.1 & 109.9 \\
\hline 27 Hovda & 6 & & 6.14 & - & 6.32 & 98.5 & 2.0 & 94.5 \\
\hline 28 Rugsvebekken & 5 & & 6.05 & 5.47 & 6.63 & 103.2 & 1.9 & 155.5 \\
\hline 29 Jernåholmen & 0 & Dest. & 6.05 & 5.47 & 6.63 & 103.2 & 1.9 & 155.5 \\
\hline 30 Svartåa 1 & 6 & & 6.13 & - & 6.40 & 168.4 & 2.6 & 130.8 \\
\hline 31 Svartåa 2 & 0 & Pred. & 6.13 & - & 6.40 & 168.4 & 2.6 & 130.8 \\
\hline 32 Deia & 4 & & 5.96 & - & 5.89 & 84.3 & 1.9 & 141.2 \\
\hline
\end{tabular}




$\begin{array}{ccccccccc}\mathrm{Ca} & \mathrm{Mg} & \mathrm{Ral} & \mathrm{Lal} & \text { Mayflies } & \text { Stoneflies } & \text { Caddisflies } & \text { Others } & \text { Tot. N } \\ \mathrm{mg} / \mathrm{l} & \mathrm{mg} / \mathrm{l} & \mu \mathrm{g} / \mathrm{l} & \mu \mathrm{g} / \mathrm{l} & \% & \% & \% & \% & \end{array}$

\begin{tabular}{|c|c|c|c|c|c|c|c|c|}
\hline 3.1 & 0.5 & 94 & 24 & 0 & 90 & 0 & 10 & 20 \\
\hline 2.6 & 0.7 & 84 & 25 & 22.9 & 64.7 & 7.1 & 5.3 & 170 \\
\hline 2.6 & 0.7 & 83 & 18 & - & - & - & - & - \\
\hline 2.8 & 0.8 & 77 & 17 & 17.4 & 63.0 & 17.4 & 2.2 & 46 \\
\hline 2.1 & 0.3 & 120 & 13 & 21.8 & 43.6 & 27.3 & 7.3 & 55 \\
\hline 2.0 & 0.3 & 115 & 19 & 21.8 & 43.6 & 27.3 & 7.3 & 55 \\
\hline 2.3 & 0.5 & 103 & 25 & 61.3 & 9.7 & 19.4 & 9.7 & 31 \\
\hline 2.4 & 0.6 & 137 & 19 & 61.3 & 9.7 & 19.4 & 9.7 & 31 \\
\hline 1.2 & 0.4 & 182 & 17 & 0.0 & 51.9 & 33.3 & 14.8 & 27 \\
\hline 1.7 & 0.5 & 219 & 5 & 1.5 & 3.5 & 91.5 & 3.5 & 201 \\
\hline 2.1 & 0.7 & 213 & 85 & 13.8 & 27.6 & 55.2 & 3.4 & 29 \\
\hline 1.1 & 0.3 & 187 & 28 & - & - & - & - & - \\
\hline 1.3 & 0.3 & 166 & 21 & 2.2 & 87.6 & 6.7 & 3.4 & 89 \\
\hline 1.6 & 0.3 & 203 & 19 & 0.0 & 61.7 & 34.4 & 3.8 & 183 \\
\hline 1.4 & 0.4 & 171 & 33 & 29.4 & 52.9 & 11.8 & 5.9 & 17 \\
\hline 1.2 & 0.3 & 215 & 25 & 0.0 & 73.8 & 22.6 & 3.6 & 84 \\
\hline 1.6 & 0.3 & 185 & 48 & 8.5 & 42.6 & 21.3 & 27.7 & 47 \\
\hline 1.7 & 0.3 & 194 & 20 & 8.5 & 42.6 & 21.3 & 27.7 & 47 \\
\hline 1.6 & 0.3 & 191 & 18 & 8.5 & 42.6 & 21.3 & 27.7 & 47 \\
\hline 1.6 & 0.3 & 191 & 18 & 8.5 & 42.6 & 21.3 & 27.7 & 47 \\
\hline 1.7 & 0.4 & 111 & 51 & - & - & - & - & - \\
\hline 1.5 & 0.4 & 150 & 23 & - & - & - & - & - \\
\hline 1.3 & 0.2 & 139 & 14 & 0.0 & 85.0 & 13.6 & 1.4 & 214 \\
\hline 1.3 & 0.2 & 139 & 14 & 0.0 & 85.0 & 13.6 & 1.4 & 214 \\
\hline 2.1 & 0.4 & 110 & 18 & 47.4 & 26.3 & 21.1 & 5.3 & 19 \\
\hline 2.1 & 0.4 & 110 & 18 & 47.4 & 26.3 & 21.1 & 5.3 & 19 \\
\hline 1.9 & 0.4 & 67 & 14 & 57.7 & 30.8 & 11.5 & 0.0 & 26 \\
\hline 2.1 & 0.5 & 177 & 16 & 0.0 & 100.0 & 0.0 & 0.0 & 27 \\
\hline 2.1 & 0.5 & 177 & 16 & 0.0 & 100.0 & 0.0 & 0.0 & 27 \\
\hline 2.7 & 0.5 & 98 & 11 & 22.2 & 55.6 & 11.1 & 11.1 & 9 \\
\hline 2.7 & 0.5 & 98 & 11 & 22.2 & 55.6 & 11.1 & 11.1 & 9 \\
\hline 2.1 & 0.3 & 76 & 7 & 18.5 & 55.6 & 7.4 & 18.5 & 27 \\
\hline
\end{tabular}


-14) were subject to special attention, as they are close to each other. River Vesleflisa was acidified with $\mathrm{pH}_{\text {Mean }}=5.17-5.39$ and $166-203 \mu \mathrm{g} / \mathrm{l}$ monomeric aluminium in autumn, compared to $\mathrm{pH}_{\text {Mean }}=5.66-6.11$ and 77-120 $\mu \mathrm{g} / 1$ monomeric aluminium in River Julussa.

\section{Successful breedings}

Thirty-three breeding attempts were recorded in the study area (Table 1), and of these 26 were successful. Water samples were not obtained from three of the breeding locations of which two were successful. These were omitted from the further analysis, which were based on 32 locations (inclusive two locations in river Vesleflisa), from which water was analysed (Table 1). In locations 13 and 14, on the Vesleflisa, no nests or nesting attempts were observed in 1998. The mean number of young in successful breeding attempts was $4.5(\mathrm{SE}=0.3)$, and per breeding attempt was $3.6(\mathrm{SE}=0.4)$.

PCA of locations with successful breeding resulted in two components with eigenvalues $>1.0$, explaining $78.8 \%$ of the total variation (Table 2, Fig. 2). The first component explaining $63.8 \%$ of variation, primarily described number of nestlings, water quality and mayfly abundance. The number of nestlings was positively related to alkalinity, $\mathrm{pH}$, calcium, conductivity and mayfly abundance, and was negatively related to water colour and monomeric aluminium. The second component, explaining $15.0 \%$ of the variation, described the relative abundance of mayflies, being negatively related to abundance of caddis flies.

The number of nestlings was significantly positively correlated (Spearman) to mean $\mathrm{pH}\left(\mathrm{r}_{\mathrm{s}}=\right.$ $0.50, \mathrm{n}=28, \mathrm{p}=0.007$ ) (Fig. 3), October $\mathrm{pH}$ $\left(\mathrm{r}_{\mathrm{s}}=0.45, \mathrm{n}=28, \mathrm{p}=0.018\right)$, alkalinity $\left(\mathrm{r}_{\mathrm{s}}=\right.$ $0.55, \mathrm{n}=28, \mathrm{p}=0.003)$, conductivity $\left(\mathrm{r}_{\mathrm{s}}=0.45\right.$, $\mathrm{n}=28, \mathrm{p}=0.016)$, calcium $\left(\mathrm{r}_{\mathrm{s}}=0.50, \mathrm{n}=28\right.$, $\mathrm{p}=0.007)$, magnesium $\left(\mathrm{r}_{\mathrm{s}}=0.44, \mathrm{n}=28, \mathrm{p}=\right.$ $0.019)$ and negatively correlated to monomeric aluminium $\left(\mathrm{r}_{\mathrm{s}}=-0.53, \mathrm{n}=28, \mathrm{p}=0.004\right)$, and non-significantly positively correlated to fraction
Table 2. Variable (number of Dipper nestlings and environmental vaiables) scores on PCA ordinated axes.

\section{Variable Component 1 Component 2}

$\begin{array}{lcc} & & \\ \text { Alk. } & 0.947 & 0.072 \\ \text { pH Mean } & 0.939 & 0.264 \\ \text { Ca } & 0.925 & -0.100 \\ \text { pH October } & 0.914 & 0.369 \\ \text { Conductivity } & 0.892 & 0.059 \\ \text { Colour } & -0.885 & -0.216 \\ \text { pH Spring } & 0.750 & 0.204 \\ \text { Al } & -0.747 & 0.411 \\ \text { Nestlings } & 0.647 & -0.024 \\ \text { Caddiesflies \% } & 0.086 & -0.936 \\ \text { Mayflies \% } & 0.518 & 0.672\end{array}$

of mayflies $\left(r_{s}=0.45, n=18, p=0.06\right)$. Alkalinity had the highest explanatory value, explaining 30 $\%$ of variation, and was positively correlated with mean $\mathrm{pH}\left(\mathrm{r}_{\mathrm{s}}=0.86, \mathrm{n}=31, \mathrm{p}<0.001\right)$, October $\mathrm{pH}\left(\mathrm{r}_{\mathrm{s}}=0.90, \mathrm{n}=31, \mathrm{p}<0.001\right)$, conductivity $\left(\mathrm{r}_{\mathrm{s}}=\right.$ $\left.0.78, \mathrm{n}={ }_{31}, \mathrm{p}<0.001\right)$, and negatively correlated with total monomeric aluminium $\left(\mathrm{r}_{\mathrm{s}}=-0.64, \mathrm{n}=\right.$ $31, \mathrm{p}<0.001)$.

\section{Unsuccessful breedings}

In the river Vesleflisa (nos. 13 - 14) that had a mean $\mathrm{pH}=5.17-5.39$ and aluminium $166-203$ $\mu \mathrm{g} / \mathrm{l}$, no breeding attempts were found after surveying thoroughly a $16 \mathrm{~km}$ stretch of the river. Potential nesting sites were checked especially, and remnants of 12 old nests at five different locations were found (i.e. one location per 3-4 $\mathrm{km}$ ) but no nest of the year was found. The newest nest was probably from the previous year. It was found in Mars and contained two unhatched eggs. Mayflies were scarce in the river Vesleflisa, compared to the neighbouring Julussa. In Julussa, with a mean $\mathrm{pH}$ ranging from 5.66 to 6.29 , six nests of the year (nos. $1-6$ ) were found within $20 \mathrm{~km}$, i.e. one nest per $3-4 \mathrm{~km}$.

Parents deserted nests/eggs for no obvious reason at three locations. At Veståa (17) with mean $\mathrm{pH}$ $=5.74$ and $185 \mu \mathrm{g} / 1$ monomeric aluminium, the nest with three eggs was deserted, at Øksna (24) with mean $\mathrm{pH}=4.99$ and $139 \mu \mathrm{g} / \mathrm{l}$ monomeric 


\section{Component Plot in Rotated Space}

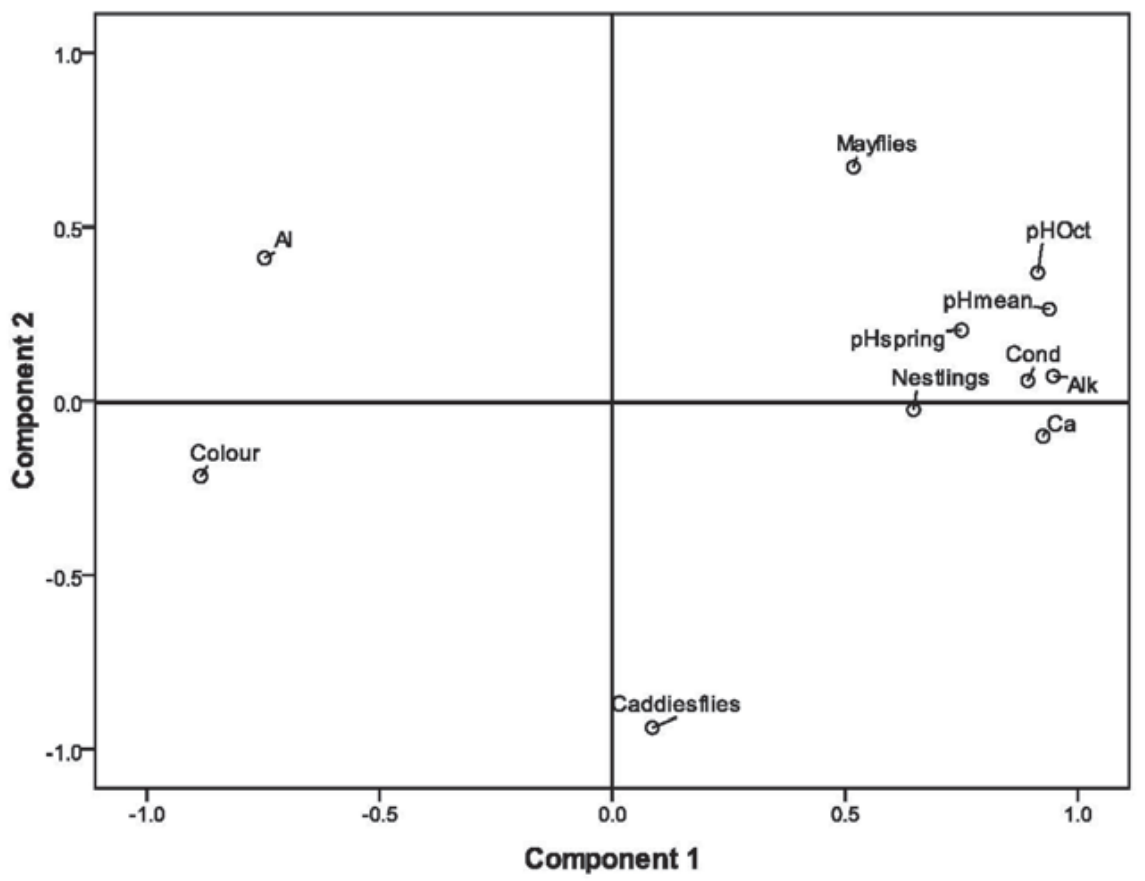

Figure 2. PCA plot of number of nestling and environmental parameters.

aluminium, the nest was deserted during incubation (inaccessibility made it impossible to count the eggs), and at Jernåholmen in the river Åsta (29) with mean $\mathrm{pH}=6.05$ and $177 \mu \mathrm{g} / \mathrm{l}$ monomeric aluminium, the nest was deserted with one egg. Four other hatching failures were observed; at location 3 (Mørstaddammen) where the nest was deserted, probably due to predation on the adults, at location 12 (Haldammen) where the nest was deserted due to human disturbance, at location 31 (Svartåa 2) where the nest was predated, and at location Agåa (location without water samples) where the nest was deserted due to human disturbance.

\section{DISCUSSION}

The correlations between the number of nestlings and water quality variables strongly suggest that acidification negatively affected the hatching success of the Dipper. The water quality parameters analysed may all be related to acidification, a result of the combination $\mathrm{pH}$ in precipitation and the neutralizing capacity of the river catchment area. The precipitation in this area had a $\mathrm{pH}$ of 4.6 in 1998 (SFT 1999), and in areas with poor quaternary deposits and abundant boglands, the $\mathrm{pH}$ in the runoff will be only slightly higher than in the precipitation. Runoff from areas with low neutralizing capacity is low in alkalinity (a good indicator of neutralizing capacity), calcium (normally strongly associated with alkalinity) and conductivity. Aluminium, on the other hand, occurs in high concentration at low $\mathrm{pH}$ as the solubility of aluminium is strongly related to $\mathrm{pH}$, with solubility increasing as $\mathrm{pH}$ decreases below 5.5 (Driscoll 1980). Although alkalinity had the highest coefficient of explanation (30 


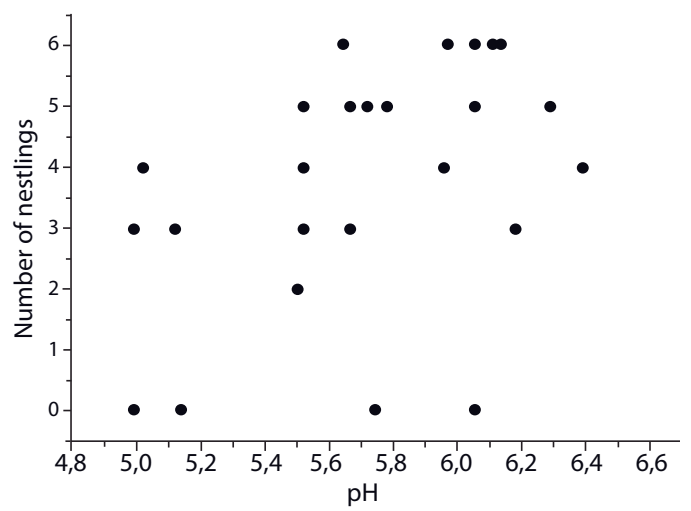

Figure 3. Number of Dipper nestlings in the broods showed positive significant correlation with $\mathrm{pH}$ at the nesting localities (Spearman rank correlations: $r_{s}=$ $0.50, n=28, p=0.007$ ).

$\%$ ), one should be careful to highlight one single parameter, as they are all affected by acidification . Alkalinity is, however, the one parameter that is most related to neutralizing capacity. Several species of mayfly, like Baetis rhodani which was recorded in Julussa (Øigarden 1999), are absent in waters with $\mathrm{pH}<5.0$, and are therefore used as indicators of acidification (Fjellheim \& Raddum 1990, Raddum et al. 1988).

The mean number of nestlings from successful breeding attempts in this study was 4.5 , which is higher than has been found in the Lyngdal area in southernmost Norway (4.0 per brood, Kurt Jerstad pers. comm.). The southernmost part of Norway is more affected by acid precipitation than SE Norway, due to both higher precipitation levels and a lower $\mathrm{pH}$ in the precipitation (SFT 1999). The positive correlation between $\mathrm{pH}$ and number of nestlings in this study corresponds to Tyler \& Ormerod's (1994) results from Wales and Vickery“s (1992) results from Scotland. They found more eggs and nestlings per brood in areas with water $\mathrm{pH}$ above 6 than in areas with lower $\mathrm{pH}$. Water acidity alone is probably not a direct toxic agent to the Dipper, but elements such as calcium and aluminium, both related to $\mathrm{pH}$, may be of importance. Calcium is important to birds during the egg-laying period as calcium is important for the formation of eggshells (Graveland \& van Gijzen 1994). Graveland et al. (1994) examined the stomach of Great Tits and found no other calcium-rich material than snail-shells and Graveland \& van Gijzen (1994) concluded that female Great Tits do not store calcium before egg-laying, but collect the calcium they need for shell formation only during the laying period. Most insectivorous and granivorous birds select additional calcium-rich material during egg-laying since their normal food contains insufficient calcium for shell formation (Graveland \& van Gijzen 1994). It is reasonable to believe that Dippers use snails and bivalves as a calcium source. Most snails and bivalves die out when $\mathrm{pH}$ is below 6.0, although some species of snail survive down to $\mathrm{pH} 5.2$ and some bivalves survive even down to pH 4.7 (Økland \& Økland 1996). In a study of dipper blood chemistry in upland Wales (Ormerod et al. 1991), the mean serum calcium concentration was significantly lower on acidic streams than in near-neutral streams in the pre-breeding period.

Low Ca-content in the diet may lead to increased Al-concentration in tissues of chickens (Nybø 1996), but the effect of aluminium is not clear. Nybø \& Jerstad (1997) reported higher aluminium in Dippers (bone and liver) in southern Norway than in North Trøndelag (in central Norway, where acidification is negligable), but there was no correlation between aluminium content and hatching success or desertion behaviour. This corroborates the results of Tyler \& Ormerod (1994) from Wales. Vickery (1992) found delayed egg-laying, fewer eggs and lighter eggs in acidified locations, and late broods tended to be smaller than early ones (Tyler \& Ormerod 1994). Though it seems clear that acidification, causing low $\mathrm{pH}$ in water low in alkalinity and calcium, has a serious negative effect on hatching success of the Dipper, the mechanism behind this effect is unknown.

Food availability for the Dipper is affected by acidification as the abundance of mayflies drops 
in acidified locations (Fjellheim \& Raddum 1990). Mayflies are an important food item, especially during the early nestling period (Ormerod et al. 1987, Tyler \& Ormerod 1994). The Dipper also eats some fish and especially in winter it may catch fry. Collett (1921) states that Dippers in winter eat a great deal of small fish, and Efteland (1983) observed Dippers on Jæren in SW Norway taking 23 small fish during $28.5 \mathrm{~h}$ of observation in winter. He also registered that fish made up $0-33 \%$ of the diet at five nest sites in the same district. Tyler \& Ormerod (1994) refer to several studies where fish comprised 0-30\% (by mass) of the diet in the breeding season and up to $65 \%$ in winter. Even if fish is not numerically common in the diet of Dippers, they may represent a considerable part by mass. Fish may thus be an important calcium source for the Dipper; especially when calcium rich prey such as snails and bivalves are missing. In the river Vesleflisa, Brown Trout Salmo trutta is missing due to acidification, whereas Perch Percafluviatilis and Pike Esox lucius still persist in slow running parts of the river (Taugbøl et al. 1996), and according to this study, the mayflies were scarce. Several factors thus affected the Dipper negatively in this river, and the sum of these probably caused the absence of Dipper in locations where remnants of old nests show that the Dipper had previously bred. The Dipper thus seems to have abandoned the Vesleflisa due to acidification, and its hatching success in locations where the Dipper still breeds was negatively related to factors reinforced by acidity. Of the seven unsuccessful breeding attempts in this study, three were due to nest desertion during egg-laying or incubation. Of these three, at least one (river Veståa) was similar to observations of desertions reported by Nyb $\varnothing$ and Jerstad (1997) in southernmost Norway and which was explained as a result of acidification.

\section{CONCLUSION}

The number of nestlings in Dipper broods was significantly correlated with $\mathrm{pH}$ and several water quality parameters related to $\mathrm{pH}$. There was also a positive trend when correlating number of nestlings with the relative abundance of mayflies, which are also affected by $\mathrm{pH}$. The Dipper in Hedmark therefore seems to have been influenced by acidification, and probably abandoned one river system due to acidification. At least one of the 33 nests observed, was probably deserted as a result of acidification. The effects of acidification varied due to local geology, and Dippers in areas of bedrock with pour quaternary deposits were seriously affected.

\section{ACKNOWLEDGEMENTS}

The paper is based on a project at Hedmark University College (Øigarden 1999). Thanks to Kurt Jerstad who gave us a Dipper field course over two days in April 1998 at his study area and who has given us much good advice. Thanks to members of the Elverum branch of Norsk Ornitologisk Forening (NOF), who supplied information of known nest sites in the area (Rune Karlstad, Arne Mæhlen, Trond Voldmo, Finn Rønning), especially Finn Rønning that joined us several days in the field. Thanks to Bjørn E. Foyn, and the Trysil branch of NOF for giving us useful advice. Thanks to Oddmund Kleven for help with the statistics.

\section{SAMMENDRAG}

For å undersøke om fossekallen Cinclus cinclus har problemer relatert til forsuring i Hedmark, ble 33 hekkinger fulgt i 1998. Det ble tatt vannprøver fra 29 lokaliteter og sparkeprøver for bunndyrinnsamling fra 20 lokaliteter. Det var 26 vellykkede hekkinger. Hekkesuksessen ble målt som antall unger ved 8-10 dagers alder etter klekking. Det ble funnet en signifikant positiv korrelasjon mellom antall unger i reirene og parameterne $\mathrm{pH}$, alkalitet og kalsiumkonsentrasjon på hekkelokalitetene. Det var også en positiv trend mellom antall unger i reirene og den relative forekomsten av døgnfluer. Det ble funnet minst ett tilfelle av skyingsadferd lik det som er beskrevet fra Lyngdalsvassdraget i Sør Norge. Det antas at 
denne adferden kan relateres til kalsiummangel. Fossekallen i Hedmark ser ut til å være påvirket av forsuringen i vassdragene. Observasjoner av skyingsadferd og korrelasjonene mellom antall unger i reirene og $\mathrm{pH}$, alkalitet og kalsium i vannprøvene gjør det rimelig å anta at i deler av Hedmark er fossekallen påvirket av forsuring og kalsiummangel.

\section{REFERENCES}

Arnekleiv, J.V. 1994. Bestemmelsesn $\phi k k e l$ til norske døgnfluelarver. Universitetet i Trondheim. Vitenskapsmuseet. Trondheim. (In Norwegian).

Brewin, P.A., Buckton, S.T. \& Ormerod, S.J. 1998. River habitat surveys and biodiversity in acid-sensitive rivers. - Aquatic conservation - marine and freshwater ecosystems 8: 501-514.

Brittain, J.E. \& Saltveit, S.J. 1984. Bunndyr. Vassdragsunders $\phi$ kelser. En metodebok $i$ limnologi. Universitetforlaget, Oslo. (In Norwegian).

Collett, R. 1921. Norges Fugle, bd. I. Aschehoug, Kristiania. (In Norwegian).

Dougan, W.K. \& Wilson, A.L. 1974. The absorptiometric determination of aluminium in water. A comparison of some Chromogenic reagents and the develop of improved metod. - Analyst 99: 413-430.

Drent, P.J. \& Woldendorp, J.W. 1989. Acid rain and eggshells. - Nature 339: 431.

Driscoll, C.T. 1980. Aqueous speciation of aluminum in the Adirondack region of New York State, USA. In Ecological Impact of Acid Precipitation, SNSF-Project (Drabløs, D. \& Tollan, A., eds.). Oslo-Ås.

Edington, J.M. \& Hildrew, A.G. 1981. A key to the Caseless Caddies Larvae of the British Isles with notes on their ecology. Freshwater Biological Association Scientific Publication No 43. Cumbria.

Efteland, S. 1983. I kva omfang kan fossekallen Cinclus cinclus ta matnyttig fiskeyngel? Vår Fuglefauna 6: 99-104. (In Norwegian).

Efteland, S. 2006. Fossekall og forsuring. - Cinclus Scandinavicus 19: 16-21. (In Norwegian).

Fjellheim, A, \& Raddum, G. G. 1990. Acid precipitation: Biological monitoring of streams and lakes. - The Science of the Total Environment. 96: 57-66.

Gjershaug, J.O., Thingstad, P.G., Eldøy, S. \& Byrkjeland, S. 1994. Norsk fugleatlas. Norsk Ornitologisk Forening, Klæbu. (In Norwegian).

Graveland, J., van Waal, R., van Balen, J.H. \& van Noordwijk, A.J. 1994. Poor reproduction in forest passerines from decline of snail abundance on acidified soils. - Nature 368: 446-448.

Graveland, J. \& van Gijzen, T. 1994. Arthropods and seeds are not sufficient as calcium sources for shell formation and skeletal growth in passerines. - Ardea 82: 299-314.

Haftorn, S. 1971. Norges fugler. Universitetsforlaget, Oslo. (In Norwegian).

Hesthagen, T., Sevaldrud, I.H. \& Berger, H. 1999. Assessment of damage to fish population in Norwegian lakes due to acidification. - Ambio 28: 112-117

Jerstad, K. 1991. Studier av sur nedbørs effekter på fossekallpopulasjonen i Lyngdalsvassdraget. Fylkesmannen $i$ Vest-Agder. 3-1991. (In Norwegian).

Jørgensen, P., Sørensen, R. \& Haldorsen, S. 1997. Kvartargeologi. Landbruksforlaget. Oslo (In Norwegian).

Jåbekk, R. 1985. Hekkesuksess hos svarthvit fluesnapper og kjøttmeis som hekker nær sure vann. Hovedoppgave. Telemark distriktshøgskole. (In Norwegian).

Kroglund, F., Hesthagen, T., Hindar,A., Raddum, G.R., Gausen, D. \& Sandøy, S. 1994. Sur nedbør i Norge. Status, utviklingstendenser og tiltak. Direktoratet for naturforvaltning. Nr. 199410. (In Norwegian).

Lillehammer, A. 1988. Stoneflies of Fennoscandia and Denmark. Fauna Entomologica Scandinavia . Vol.21.E.J.Brill/Scandinavian Science Press Ltd. Leiden.

Muniz, I. P. 1990. Freshwater acidification-its effects on species and communities of freshwater microbes, plants and animals. - Proceedings of the Royal Society of Edinburgh, section B-Biological Sciences. 97: 227-254.

Nybø, S. 1996. Effects of dietary aluminium on chicks Gallus gallus domesticus with different dietary intake of calcium and phosphorus. Arch Environ Contam 31: 177-183.

Nybø, S. \& Jerstad, K. 1997. Fossekallen; hva vet vi om virkninger av sur nedbør, kalking og miljøgifter? Direktoratet for naturforvaltning. Nr. 1997-8. (In Norwegian).

Nybø, S., Staurnes, M. \& Jerstad, K. 1997. Thinner eggshells of Dipper (Cinclus cinclus) eggs from an acidified area compared to a nonacidified area in Norway. - Water Air Soil Pollut 93: 255-266.

Nyholm, N.E.I. 1981. Evidence of involvement of aluminium in causation of defective formation of eggshells and of impaired breeding in wild passerine birds. - Environ Res. 26: 363-371.

Nyholm, N.E.I. \& Myhrberg, H.E. 1977. Severe eggshell defects and impaired reproductive capacity in small passerines in Swedish Lapland. - Oikos 29: 336-341.

Ormerod, S.J., Efteland, S. \& Gabrielsen, L.E. 1987. The diet of breeding Dippers Cinclus cinclus cinclus and their nestlings in south western 
Norway. - Holarctic Ecology 10: 201-205.

Ormerod, S.J., O'Halloran, J., Gribbin, S.D. \& Tyler, S.J. 1991. The ecology of Dippers Cinclus cinclus in relation to stream acidity in Upland Wales: breeding performance, calcium physiology and nestling growth. - Journal of Applied Ecology 28: 419-433.

Overrein, L., Seip, H. M. \& Tollan, A. 1980. Acid precipitation - effects on forest and fish. SNSF-project, FR 19/80.

Raddum, G. G., Fjellheim, A \& Hesthagen, T. 1988. Monitoring acidification through the use of aquatic organisms. - Verh. Int. Verein. Limnol., 23: 2291-2297.

Rognerud, S. 1992. Water quality survey in Hedmark county. A regional survey in 220 lakes in autumn of 1988. - Norwegian institute for water research. Report LNR 4/92.

Rosseland, B. O., Kroglund, F., Staurnes, M., Hindar, K. \& Kvellestad, A. 2001. Tolerance to acid water among strains and life stages of Atlantic Salmon (Salmo salar L.). - Water Air and Soil Pollution 130: 899-904.

Sigmond, E.M.O., Gustavson, M. \& Roberts, D. 1984. Berggrunnskart over Norge. M 1:1 mill. Norges Geografiske Unders $\varnothing$ kelser. Hønefoss. (In Norwegian).

SFT 1999. Monitoring long-range transboundary air pollution 1998. State Pollution Control Authority Rep. 768/1999.

SFT 2007. Monitoring long-range transboundary air pollution 2006. State Pollution Control Authority Rep. 988/2007.

Snow, D.W. \& Perrins, C. M. 1998. The Birds of the Western Palearctic. Concise Edition. Oxford University Press, Oxford.

Taugbøl, T., Linløkken, A. \& Solvang, H. 1996. Konsekvensutreding Regionfelt Østlandet. Tema: Fisk. Østlandsforskning. Rapport $n r$. 12/1996. (In Norwegian).

Thoresen, M.K., Norges geologiske unders $\emptyset$ kelser. 1990. Jordarter. M 1:1 mill. Nasjonalatlas for Norge, kartblad 2.3.7. Statens kartverk. Hønefoss. (In Norwegian).

Tyler, S. \& Ormerod, S. 1994. The Dippers. T. \& A. D. Poyser, London.

Vickery, J. 1992. The reproductive success of the Dipper Cinclus cinclus in relation to the acidity of streams in south-west Scotland. Freshwater Biology 28:195-205.

Wallace, I.D., Wallace, B. \& Philipson, G.N. 1990. A key to the Case-bearing Caddis Larvae of Britain and Ireland. Freshwater Biological Association Scientific Publication No 51. Cumbria.

Øigarden, T. 1999. Fossekallen i Hedmark; er hekkesuksessen påvirket av sur nedbør? Prosjektoppgave ved Hogskolen i Hedmark, avd. for landbruks- og naturfag, Blasstad. (In Norwegian).

Økland, J. \& Økland K. 1996. Dyreliv $i$ vann og vassdrag. J. W. Cappelens forlag, Oslo. (In
Norwegian).

Østnes, J.E., Jerstad, K. \& Skåtan,J.E. 1999. Effekter av skjellsand på hekkesuksessen hos Fossekall (Cinclus cinclus) i sure vassdrag i Vest-Agder. - Allforsk rapport 14: 1-21. (In Norwegian). 